OPEN ACCESS

Edited by:

Joni Jupesta,

SMART Research Institute (SMARTRI),

Indonesia

Reviewed by:

Joseph Anthony Lazareto Reyes, University of Exeter, United Kingdom Laurence Delina,

Boston University, United States

*Correspondence:

Sergio Ruiz Cayuela ad0015@coventry.ac.uk

Specialty section

This article was submitted to Energy Systems and Policy,

a section of the journal

Frontiers in Energy Research

Received: 31 July 2018 Accepted: 07 December 2018 Published: 04 January 2019

Citation:

Ruiz Cayuela S and Turhan E (2019) Wasting Democracy, Fueling Dissent:

Refuse-Derived Fuels in Can Sant Joan (Catalonia).

Front. Energy Res. 6:142. doi: 10.3389/fenrg.2018.00142

\section{Wasting Democracy, Fueling Dissent: Refuse-Derived Fuels in Can Sant Joan (Catalonia)}

\author{
Sergio Ruiz Cayuela ${ }^{1,2 *}$ and Ethemcan Turhan ${ }^{1}$ \\ ${ }^{1}$ Environmental Humanities Laboratory, Division of History of Science, Technology and Environment, KTH Royal Institute of \\ Technology, Stockholm, Sweden, ${ }^{2}$ Center for Agroecology, Water and Resilience, Coventry University, Coventry, \\ United Kingdom
}

The cement industry is one of the most energy intensive in the world, contributing significantly to global greenhouse gas emissions. The use of refuse-derived fuels (RDF) in cement kilns is increasingly portrayed as a sustainable solution to reduce emissions while dealing with different types of waste. Nevertheless, the use of RDF in cement plants is contested by communities around the world, who are facing immediate environmental impacts. In this article, we examine the burgeoning movement against waste incineration in cement kilns legitimized as energy recovery. We start by revisiting the environmental justice literature, which laid the groundwork for the contemporary anti-RDF movement. Then, in order to highlight the energy dimension of RDF we focus on two energy-related concepts: energy justice and energy democracy. Through the case study of Can Sant Joan (Catalonia), we assess the suitability and usefulness of these concepts with the local movement against waste incineration. Our analysis suggests that the movement against RDF use can be further energized and strengthened by expanding into the realm of energy democracy. Both the anti-RDF and the energy democracy movement share a focus on the local scale, have similar typology of stakeholders involved, and favor a strong bottom-up approach while paying attention to unequal power relations. We also observe that these movements can mutually benefit from being better integrated with one another. Finally, we propose that a potential alliance between the Plataforma Antiincineració de Montcada i Reixac (PAMiR) and the Xarxa per la Sobirania Energètica (Xse) in Catalonia, can mobilize fruitful internal tensions toward a more inclusive and democratic future.

Keywords: energy democracy, refuse-derived fuels, environmental justice, waste incineration, energy justice, energy sovereignty

\section{INTRODUCTION}

The cement industry is relatively understudied from social sciences perspective on energy research, although it is among the most energy intensive sectors in the world. Global cement industry is responsible for $7 \%$ of the global $\mathrm{CO}_{2}$ emissions and accounted for $6.5 \%$ of total industrial energy use in 2016, making it one of the largest industrial energy consumers behind chemical industries, refineries and iron-steel production (IEA, 2018a; IEA and CSI, 2018). Global cement production grew by 73\% from 2005 to 2013 (CEMBUREAU, 2013) mainly driven by rapid "planetary urbanization", and recent projections expect annual production to increase by an additional 50\% by 2050 (Monteiro et al., 2017). The strong relation between high-energy consumption (mainly provided 
by coal, but also increasingly so by alternative fuels) and greenhouse gas (GHG) emissions make the cement industry one of the key culprits of climate change (Akhmat et al., 2014). In fact, recent estimates show that cement production accounts for $5-8 \%$ of global anthropogenic GHG emissions (Mikulčić et al., 2016). Increasing attention on climate policies after the Paris Agreement has led the cement industry to take a "green turn" and seek ways of reducing its carbon footprint (WBCSD, 2015). Among the several GHG emissions reduction strategies that have been devised in recent years, one of the most promising is the substitution of primary energy sources used in the kiln from fossil fuels to refuse derived fuels (RDF)-including municipal solid waste, sewage sludge, biomass, animal meat, and bone flour as well as end-of-life tires (Kajaste and Hurme, 2016). The use of RDF minimizes production costs and reduces the demand of fossil fuel extraction. It also lowers GHG global emissions by replacing fossil fuels with materials that would anyway have to be incinerated or disposed as solid waste in landfills (Chatziaras et al., 2016).

At national and international scale RDF use has been praised as a promising solution to reduce GHG emissions from the cement industry by global environmental groups (Müller and Harnisch, 2008), United Nations environment and development organizations (e.g., CTCN, 2015), engineering scholars (e.g., Kara, 2012; Mikulčić et al., 2016), the European Commission (European Commission, 2017), and other European institutions working at a global level (such as the German Development Cooperation Agency (GIZ) and the Nordic Development Fund among others) (Herrero and Vilella, 2018). However, the highly heterogeneous nature of the RDF input (both physically and chemically) in comparison to more traditional fossil fuels limits the share of RDF used in the mix of a cement kiln. Ultimately, this leads to decreased efficiency in the production process, with adverse consequences on cement quality (Liedmann et al., 2017). On top of these rather technical challenges, dissenting voices in academic and activist circles point to the dangerous impacts this practice might have, given the absence of strict environmental guidelines, especially at a local level. Several studies have pointed to health risks and especially higher cancer mortality in towns in the vicinity of cement installations (e.g., García-Pérez et al., 2013, 2015; Valls Llobet, 2018). Environmental activists go even further and add to the well-documented adverse environmental health effects, undesired social and economic impacts in the production of RDF, such as job displacement and occupational health issues (Shah et al., 2013). It is at local scale, though, where the use of waste as a fuel substitute in cement production is facing the most consolidated resistance. Communities living in the vicinity of cement plants often report high levels of cancer and respiratory diseases rates, which they attribute to industrial pollution and, more recently, to RDF use (García-Pérez et al., 2015). Consequently, communities across the world are mobilizing and creating regional and global activist networks, in what can already be defined as a global movement against waste incineration in cement plants (Simon, 2014; Donoso, 2017; Franklin, 2017).

In this paper, we provide one of the first attempts to scrutinize RDF from the vantage point of energy democracy using the theoretical toolbox of environmental justice (EJ). In what follows, we first examine the current evolution of the burgeoning global movement against waste incineration in cement plants. Then, building on the existing literature on energy justice and energy democracy, we explore the specific features of both, as movements and scholarly concepts, through which we trace resemblances, divergences, and complementarities between them. Consequently, by taking Can Sant Joan (Catalonia) as a case study, we analyze the movement against waste incineration in cement plants in terms of energy justice and energy democracy. In the final part of the paper, we argue that communities opposing RDF use in cement plants, as well as activist networks against waste incineration in other places, could benefit by explicitly framing their struggles as a matter of energy democracy. We conclude with some ideas for further research directions.

\section{ENVIRONMENTAL JUSTICE AND WASTE INCINERATION: A BRIEF REVIEW}

As the by now well-known social history suggests, the EJ movement emerged in the 1980s in the USA in close connection with the civil rights movement. Bringing together racial and ethnic discrimination with unequal distribution of environmental hazards, this sprawling movement helped uncover environmental racism inherent in advanced industrial societies (Pellow, 2000; Cutter, 2006). Initially the movement focused on the empowerment of urban communities by means of local activism to revert the unequal distribution of environmental burdens, targeting distributional, and procedural justice concerns (Schlosberg, 2009). During the Clinton administration, the US-based EJ movement achieved political recognition and a new phase opened for EJ struggles on a large-scale policymaking front, as represented by the Executive Order 12898 on Environmental Justice (Bullard and Johnson, 2000). Outside the USA, a global EJ movement has been surfacing under different names and forms (Armiero and Sedrez, 2014). In the past 20 years, this eclectic movement further came of age further by embracing environmental conflicts as leverages for broader social justice concerns and in full recognition of their potential to transform socio-metabolic configurations (Di Chiro, 2016; Martinez-Alier et al., 2016; Scheidel et al., 2018). EJ research has classically been framed around the distribution of environmental hazards and risks, and more specifically the consequences for human health. More recently, with the advent and strengthening of global commodity chains, new explorations on the commodity frontiers and a renewed focus on the multi-scalar nature of environmental ills, the scope of what is perceived as risk has also gradually been expanded toward more-than-human worlds (Reed and George, 2011; Groves, 2015). Both the social movements and the research field of EJ have been steadily shifting toward a more open understanding of the concept, bridging alliances with other movements, embracing intersectionality (Di Chiro, 2008) and advancing its agendas. This move has allowed EJ to increase its influence in policy-making and, especially, in key fields of food, water, energy and climate (Agyeman et al., 2016). Despite the expanding scope of EJ, until recently the questions on 
energy, justice and democracy have not been tackled as a major concern, neither by the movement nor the academic field (Hess and Ribeiro, 2016; van Veelen and van der Horst, 2018).

Waste has been closely related to EJ from the beginning of the movement. In fact, a key moment in the history of the EJ movement happened in 1982 in Warren County, North Carolina, when the local community was joined by civil, environmental and religious organizations to resist the sitting of a hazardous waste landfill (Bullard, 1990). Waste, after all, is not a thing, but a social relation (Armiero and De Angelis, 2017). In this sense, disposal or reuse of waste results in a kind of sorting exercise, aiming at separating "the desirable from the unwanted; the valuable from the worthless, and indeed, the worthy or cultured from the cheap or meaningless" (Scanlan, 2005, p. 9). As awareness of the risks posed by incineration gradually built up around the world, communities increasingly became organized in their opposition to incineration facilities in their vicinity (Rootes, 2009). Consequently, waste incineration has been a major concern of the EJ movement in and beyond the USA, as extensive and relevant literature proves (e.g., Sze, 2006; Lang and Xu, 2013; Laurian and Funderburg, 2014; Demaria and Schindler, 2016). Struggles against waste incineration worldwide are grounded in the relationship between the environment and public health, as well as distributional issues-waste is not usually burned in the geographical area where it is produced, creating environmental injustices. Whereas, local communities in the USA have strategically used the concept of EJ in their struggles, in other parts of the world the dimensions of the movement have usually been articulated through different and more disparate concepts (Herrero and Vilella, 2018). A global movement against waste incineration emerged in 2000 with the formation of the Global Alliance for Incinerator Alternatives/Global Anti-Incinerator Alliance (GAIA). Currently comprising more than 800 grassroots groups, non-governmental organizations and individuals in over 90 countries, GAIA seeks to empower communities worldwide to achieve three main goals: resource conservation, sustainable economic development and environmental justice ${ }^{1}$. Campaigns against Refuse-Derived Fuels (RDF) - also known as waste-to-energy or waste-of-energy (Energy Justice Network, 2018)-are some of the key actions of this global movement against incineration. Yet, campaigners against RDF have, so far, predominantly focused on waste issues, while attending to a lesser extent to the implications of incineration for energy production.

Our empirical attention here is toward the community responses to $\mathrm{RDF}$, within the context of cement production constituting a highly polluting industry with plummeting demand since 2009 (Revill, 2017). Pirani (2018) reports that between 1970 and 2005, annual global output of cement rose by $271 \%$ with most of the production now taking place outside of OECD countries. Accordingly, global cement production accounted for $3.1 \%$ of total global energy use in 2011 (ibid.: 76), the bulk of which came from coal combustion. These troubling figures have prompted the International Energy Agency to call

${ }^{1}$ GAIA (n.d.) About GAIA. Available online at: http://www.no-burn.org/aboutgaia for doubling the use of alternative fuels in cement production by 2030 (IEA, 2018b). It is not only that the cement production process is highly energy intensive, but also it has proven to be the greatest commercial success for recycling of side products from the energy industry. This includes, for example, coal ash, one of the most prominent and enduring waste legacies of twenty-first century (Trumpeter, 2012, p. 132). As well as this residual waste, the car tire industry is also eager to link up with cement production; using tires for combustion in a cement kiln supposedly produces 25 percent more energy than coal (Leandro, 2012, p. 918). Moreover, some studies even suggest that high quality RDF can be a good substitute to "replace fossil fuels primary energy" (Bras et al., 2017). However, such technical fixes often come at the expense of discarding concerns of particular communities in particular places. These communities are thereby rendered as subaltern and places as sacrifice zonesmeaning areas bearing with an abnormally high number of locally unwanted land uses (LULUs) (Lerner, 2010). As the Cerrell Report uncovered in 1984, these LULUs are deliberately placed in the vicinity of marginal communities - that have less political incidence and are less likely to resist-following a rationale known as "the path of least political resistance" (Faber, 2018, p. 62). RDF is a good example of distributional concerns linked to techno-optimism trends. Sacrifice zones host only the most polluting stages of the waste-to-energy process-especially waste incineration-whereas more affluent areas produce most of the waste and consume most of the energy (Martinez-Alier et al., 2010). Thus, struggles against waste incineration in cement plants bring together political ecologies of waste, energy, and even the built environment, in places where the political power of the community is not easily visible. Yet, as Armiero and Sedrez (2014, p. 9) suggest, "subaltern environmentalism [...] chooses to focus on urban and work environment and, more precisely, on the connections between economic production and public health," thus giving subaltern communities leverage for challenging basic political economic assumptions while bringing multiple agendas together. In the next section, we revisit the existing research literature before moving on to our case study with an empirical focus on resistance against RDF.

\section{ENERGY JUSTICE VS. ENERGY DEMOCRACY: WHAT IS IN A WORD?}

The term energy justice was first used as a specific type of EJ by a limited number of US based-and later on UK based-environmental groups in the late 1990s and early 2000s (Heffron and McCauley, 2017). Nevertheless, recent studies have shown that notions of justice in relation to energy systems are mainly implicit in the discourses of activist and advocacy groups, whereas the explicit term "energy justice" is rarely deployed (Fuller and McCauley, 2016). Though this concept did not receive full attention in academic circles prior to the 2010s, in the past few years it rapidly gained momentum among scholars. Today, there are two main currents of energy justice that compete, but at the same time also complement each other (Heffron and McCauley, 2017). The 
first approach seeks to include dimensions of distributional, procedural and recognition justice to decision-making processes along the whole energy system, including not only production and consumption but the whole life cycle from mining to waste management (Heffron and McCauley, 2014; Jenkins et al., 2014). The second approach, as operationalized by works such as Sovacool and Dworkin (2014), Sovacool et al. (2017), and Delina and Sovacool (2018), focuses on a set of principles that contribute to reframing energy policies and technology as justice matters. These principles are availability, affordability, due process, transparency and accountability, sustainability, intragenerational equity, intergenerational equity, responsibility, resistance, and intersectionality (ibid.). In this framing, energy justice is multifaceted. It is, at the same time, a conceptual tool that integrates distributive, procedural, cosmopolitan, and recognition justice; an analytical tool helpful to reframe energy problems; and a decision-making tool for planers and consumers. Scholars of energy justice argue that it is more strategically impactful than EJ and climate justice-concepts upon which it is built-for three main reasons (Jenkins, 2018). First, energy justice "provides a way of "bounding" and separating out energy concerns from the wider range of topics addressed within both environmental and climate justice campaigning" (Bickerstaff et al., 2013, p. 2). Second, it is a term not frequently used in activism and, thus, it keeps a policy-oriented focus that allows for rapid and systematic implementation. And third, a rich body of academic knowledge has been produced on energy justice, including tools, methodologies and frameworks very relevant to policy and decision-making (Jenkins et al., 2018; Monyei et al., 2018).

During the last decade, academics and civil society mobilized another term, energy democracy, in order to bring their concerns closer to organizations pushing for the decarbonization of the energy sector (Kunze and Becker, 2014; Duda et al., 2017; Fairchild and Weinrub, 2017). As van Veelen and van der Horst (2018) argue, energy democracy is not only about "how" questions of transitioning away from fossil fuels, but also about determining what "type" of democratic futures we are after. These authors posit that energy democracy, with its useful vagueness, can better be operationalized once it tackles difficult questions around scale, materiality, and deliberation of energy decisions (ibid.). More recently, energy democracy has been used and operationalized by diverse actors in the US and Europe, including activist and advocacy groups, trade unions, scholars and political parties (Burke and Stephens, 2017, 2018). In conceptualizing this term, Szulecki (2018) identifies at least two framings of energy democracy in the non-academic literature. The first framing renders it as a conceptual frame for energy transformations, in which four dimensions are emphasized: democratization; property; surplus value production and employment; and ecology and sufficiency (Kunze and Becker, 2014). The second framing treats energy democracy as a political process to describe ongoing social, technical, economic, and political experiments that seek to decentralize and disperse energy production and governance. Advocates of energy democracy argue that renewable energy technologies would allow more flexibility and modularity within the energy system, but also transform ownership structures (Bozuwa, 2018). Thus, they see in the energy transition toward renewables an opportunity to effect broader socio-political transformation and thus plant the seeds of an "energy revolution" (Abramsky, 2010; van Veelen, 2018). Energy democracy arguably brings energy decision-making back into the political terrain by moving beyond acknowledging injustices in the energy realm and in doing so, offering a "radical, systemic and politically oppositional project" (Healy and Barry, 2017). Therefore, it also pays particular attention to the political economy and organizational dimensions of both fossil fuel and renewable energy to avoid replicating the existing political and economic dynamics embedded in the present-day energy system (McCarthy, 2015; Skandier and Bozuwa, 2018). Consequently, following TUED's (2013) agenda setting report, Burke and Stephens (2017, p. 37) identified three main goals of energy democracy practice as: "resist [ing] the dominant fossil-fuel agenda, reclaim[ing] social and public control over the energy sector, and restructur[ing] the energy sector to better support democratic processes, social justice and inclusion, and environmental sustainability" (our emphasis).

Although it is possible to trace common goals, a widelyaccepted definition of energy democracy is still at large, something that Hess (2018) identifies as a strength rather than a weakness. Hess argues that energy democracy has a high potential to build bridges among stakeholders with diverse goals and strategies in order to form strong energytransition coalitions. Accordingly, the imposition of a clear-cut definition would be limiting. Burke (2018) goes even further and argues that the existence of different approaches and narratives around energy democracy can activate productive tensions among groups and organizations working toward democratizing the renewable energy transition. Furthermore, Szulecki (2018) highlights the importance of advancing energy democracy at multiple governance scales and considers the lack of a specific definition a limitation to the design and implementation of policies at national level. Along these lines, Szulecki proposes a definition of energy democracy based on three levels that can be operationalized with specific indicators: (a) democratic popular sovereignty; (b) participatory governance; and (c) civic ownership (ibid). Central to this definition is the figure of the prosumer-a subject involved in both the production and consumption according to Ritzer (2010). In relation to energy democracy a prosumer should be informed and conscious, and directly and indirectly politically engaged. In this conceptualization of energy democracy, the popular democratic domain is expanded to include not only the national and local scale, but also private energy choices (Szulecki, 2018). Therefore, the key features of energy democracy, both as an analytical tool and normative goal, feature in its explicit focus on (a) decentralization of production, (b) change of ownership structures, and (c) attention to sovereignty beyond the nationstate (Becker and Naumann, 2017). Despite the innovations brought forth by energy democracy and energy justice literatures, the bulk of research still focuses on electricity provision and distribution and much less so on other end uses of energy. Our main contribution here is to mobilize an energy democracy framework in analyzing the resistance against the use of refuse derived-fuels in the cement industry. 


\section{METHODOLOGY}

The aim of this paper is to operationalize energy democracy by applying it to a case study of activism against RDF use in cement kilns. In order to deepen our investigation, we preferred a single in-depth case study approach complemented with archival research in order to verify the main line of inquiry (Yin, 2003). Specifically, we focused on the local movement against RDF use in the Asland cement plant of Can Sant Joan (Catalonia). This case study was selected for two main reasons: first, our acquaintance with the activist landscape in the community; and second, the increasing convergence of Catalan networks against waste incineration, with those networks promoting energy democracy/sovereignty in a politically contentious region in southern Europe. Moreover, the community of Can Sant Joan provides an internationally recognized case among the global movement against RDF use in cement kilns (Herrero, 2015). Yet, while we consider the case study of Can Sant Joan analytically informative, we do not necessarily claim replicability as to how energy democracy can be operationalized at the local level.

The fieldwork for this research was conducted by the first author during February 2017. We had extensive preliminary correspondence with two key informants, both of whom provided access and contacts in the field. The first was José Luis Conejero, president of the neighborhood association of Can Sant Joan and a member of the Anti-Incineration Platform of Montcada i Reixac (referred to as PAMiR, its Catalan acronym hereafter). The second was Núria Vidal de Llobatera, a member of Ecologistes en Acció and former worker of Montcada i Reixac (MiR) municipality for 20 years in the field of environment ${ }^{2}$. The main data was derived from 21 semi-structured interviews, all transcribed and $\operatorname{coded}^{3}$. The interviews were conducted in the languages of Catalan and Spanish. Whilst care was taken to ensure wholly accurate translation, we claim full responsibility should there be any (minor) mistranslations within the extracts quoted in the text. For the selection of the interviewees we used snowball sampling, building upon the information obtained from our key informants. By triangulating the information from multiple sources, we sought to accurately represent all the parties in the ongoing local struggle against RDF use; including members of the PAMiR, the neighborhood association, the local women and youth groups, local politicians and municipal employees, managers of the cement plant, scientists, practitioners, and members of environmental advocacy groups. In doing so, we also benefitted from a range of different data sources. This included: formal documentationair quality reports produced by the community, scientific studies

\footnotetext{
${ }^{2}$ Originally a Catalan company, Asland built the Montcada i Reixac cement plant in 1917. It was later wholly acquired by Lafarge in 1993.

${ }^{3}$ For full disclosure, there was only one interview where we could not obtain a signed informed consent: the interview with the cement plant managers. Despite having previously sent the form and informed these informants that they need to sign if they wanted the information they provided to be included in the research study, these informants suggested they needed clearance from the company's legal department and never sent the signed form back. Thus, no information from these informants was directly used in this case study. Nevertheless, we consider it fair to use information from our visit to the cement plant in the form of direct observations while not making reference to the words of our interviewees.
}

conducted by environmental organizations, peer reviewed scientific papers, and legal documents; archival recordsmunicipal contracts, historical correspondence involving the municipality, the complete collection of the Can Sant Joan monthly magazine Hoja Informativa (1966-2017), organizational budgets, and economic and demographic data; and direct observations in the field. Our focus incorporated an attention to physical artifacts such as graffiti (see Figure 1) and other artistic forms of resistance in the neighborhood.

\section{CASE STUDY}

\section{The Can Sant Joan Community}

Can Sant Joan is a poor, working-class, migrant neighborhood (Arbiol Ballarín, 2015), which belongs to the municipality of MiR in the outskirts of Barcelona (see Figure 2). It was born at the beginning of the twentieth century as a settlement where the unskilled laborers working at the railway line and the Asland cement plant resided. The neighborhood underwent dramatic transformations during the 1950 and 1960s in the context of mass migration wave from rural to industrial areas in Francoist Spain. A process of spontaneous urban development took place at the time, which skyrocketed the local population and filled the previously uninhabited areas in the neighborhood with shacks. The foundation of the neighborhood association in 1960, the first one created in Catalonia, also helped to create a common identity among residents who literally came from all Spanish regions. Since then, the neighborhood association has always had a prominent role in fostering conviviality in the community and, especially, in struggling to improve local living conditions. Already born in the shade of two noxious infrastructuresnamely the cement plant and the railroad tracks-Can Sant Joan's condition of "sacrifice zone" was progressively reinforced with the siting of new hazardous industries and infrastructures in close vicinity.

The very first urban waste incinerator installed in the Spanish state was placed in Can Sant Joan in 1974. Nevertheless, more visible pollution from the Asland cement plant centered the opposition of the neighbors at the time. As Manolo Gómez, a resident of Can San Sant Joan and member of the neighborhood association, puts it: "the big chimney at the cement plant was releasing huge dust clouds 24 hours a day. Every morning the whole neighborhood would be covered with a thick gray layer of cement dust" (interview February 6th 2017). In 1987, popular mobilization pushed the municipality to enforce the installation of modern filter technologies at the cement plant and the public eye turned toward the incinerator. Legitimized by the active involvement of a local doctor, the community started to point to the incineration facility as the cause for a dramatic increase in cancer and respiratory diseases in the neighborhood. In the words of José Luis Conejero, president of the neighborhood association, "this doctor [...] was the first one who dared to link our health problems with pollution, and raised awareness among the neighbors" (interview February 6th 2017).

Large popular mobilizations, led by the neighborhood association at the beginning of the 1990s, also attracted municipal support in the campaign against waste incineration in Can Sant 


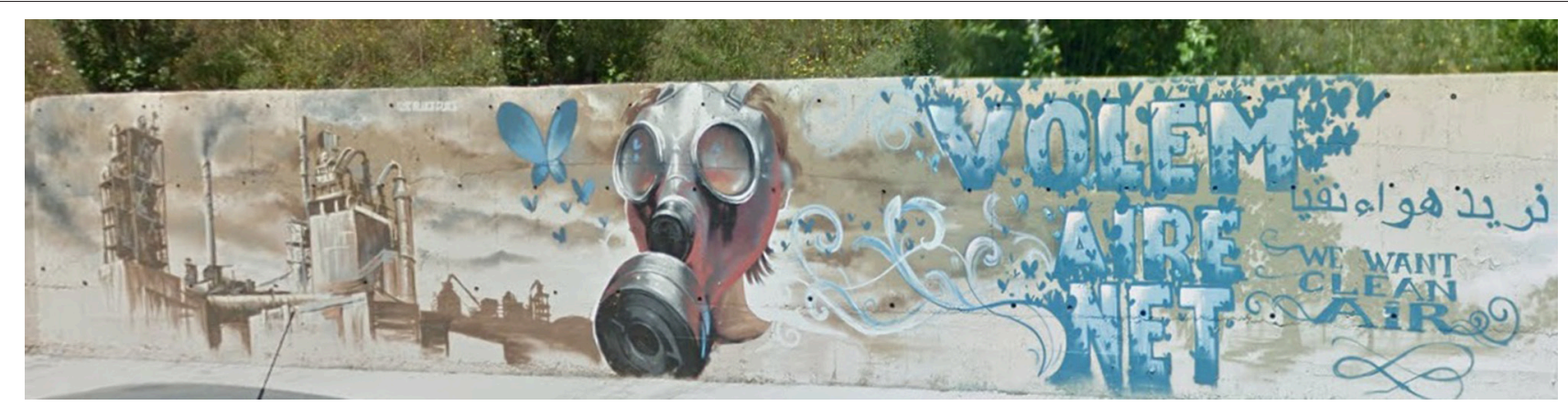

FIGURE 1 | Street art against RDF in Can Sant Joan. Source: own picture.

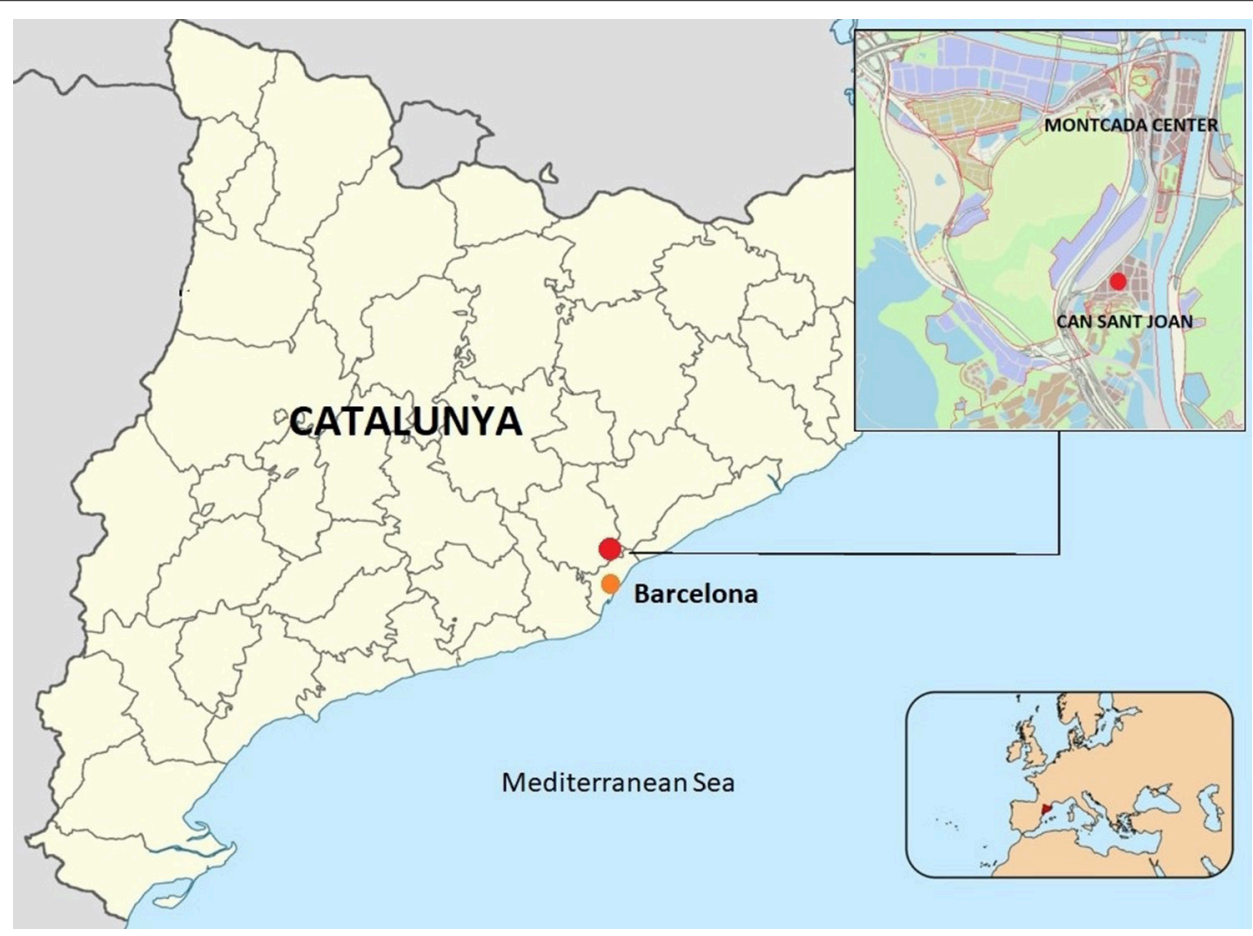

FIGURE 2 | Geographical location of Can Sant Joan. Source: own production.

Joan. This was formalized through the approval of a motion in 1999 that banned waste incineration within MiR boundaries. The incinerator was finally shut down in 2004 and substituted by Ecoparc 2, an urban waste management plant that performs mechanical and biological treatment. This solution partially satisfied the community since the new facilities were placed 5 kilometers away from the neighborhood and 1 kilometer away from the closest residential area. Nevertheless, local activists remained suspicious of the processes undertaken in Ecoparc 2 for not dealing with waste disposal issues. Their distrust proved correct 2 years later, when the Asland cement plant received an official permit to start using RDF in the fuel mix of their kiln including urban waste, sewage sludge, plastics, meat flour and waste from the pharmaceutical industry among others (Baltasar i Albesa, 2008). In the next section, we focus on the local movement that emerged against RDF use in Can Sant Joan, building on the combative tradition of the community and the experience of opposing a waste incineration facility in the past.

\section{The Movement Against RDF Use in Can Sant Joan and Beyond}

In December 2006, after learning that the Asland cement plant obtained permission to use RDF, local activists started organizing the community against the cement plant. This call rapidly rooted in the consciousness of the neighbors, including for the fact that the smokestack is located just 150 meters away from a primary school and a football field. During the first 14 months, a local platform (PAMiR) was created and a fierce environmental struggle took place in Can Sant Joan. Eventually, an 18-month moratorium against RDF use was enforced by the Catalan government in February 2008. Today, after some 10 years, despite going 
through different phases and the local movement now turning into a leading movement against waste incineration at the international level, within Can Sant Joan this conflict still remains.

The main goal of the movement against RDF in Can Sant Joan is not just the relocation of the cement plant, but the complete closure of the factory. Local activists explicitly claim to not be a NIMBY ${ }^{4}$ movement, as they highlight the prioritization of reducing consumption of cement. The movement revolves around two main axes, that at times contradict each other in their relation to governmental bodies: one part of the struggle is focused on local environmental health issues; the other part is mainly centered on political economic dynamics of cement production and waste as a fuel input in this process. The community's close collaboration with scientists and practitioners has further fostered the use of environmental health focused scientific language by local activists. This axis of the movement depicts the struggle as a matter of public health by highlighting high rates of cancer and respiratory diseases in the neighborhood and nearby communities. As José Luis Conejero-president of the neighborhood association-puts it: "we have learned from several scientific studies that pollution is causing a high number of deaths and diseases in Can Sant Joan, and I firmly believe it is caused by the cement plant. The problem is that until we get an epidemiologic study we cannot determine the source with absolute certainty" (interview February 6th 2017). The use of technical language and the alliance with several researchers and practitioners legitimizes the struggle at the level of mainstream politics.

Local activists have organized the movement along four main lines of action: protest actions, legal actions, street science and bridging alliances. Very diverse and imaginative protest actions have been carried out by the PAMiR in the last decade. They have included demonstrations with up to 2,000 people, sabotaging of public events in which local authorities took part, themed carnivals, production of the movie "Arcángeles" in which pollution from the Asland cement plant originates a zombie epidemic, organizing the "Estem Cremats" ("We are burned" in Catalan) music festival, and gaining public support by celebrities in media appearances. Some of these protest actions have created great controversy due to direct confrontation with workers from the Asland and other cement plants. As a Can Sant Joan neighbor puts it "several times LafargeHolcim [current owner of the cement plant, a.n.] has fleeted buses from Sagunt and other Spanish towns in order to bring workers and threaten the neighbors that were demonstrating" (interview March 10th 2017). When it comes to legal actions, the PAMiR has started two lawsuits against the Asland: one on irregularities in the environmental impact assessment related to $\mathrm{RDF}$ use in the cement plant that led to the aforementioned moratorium in 2008; and another-still ongoing-on exceeding permissible noise levels in the neighborhood. Several crowdfunding campaignssome of them related to protest actions-have been organized to defray the legal costs. Community members have made use of street science (Corburn, 2005) to oppose Asland's narrative

${ }^{4}$ NIMBY is the short form for "Not-in-my-backyard." about traffic being the almost exclusive source of pollution in the neighborhood. PAMiR activists have taken part in the co-production of knowledge with scientists and practitioners. Moreover, dissemination talks chaired by renowned researchers have been organized in and beyond the neighborhood, in order to raise awareness and increase the critical mass of the movement. Local activists have also engaged in joint activities with universities at undergraduate and postgraduate levels. The PAMiR has also put a lot of effort in building coalitions.

Unlike the struggles waged against the cement plant in the late 1990s, this time around the neighborhood association has made greater effort to seek external support for their cause against RDF use in the Asland cement plant. A first step toward building new coalitions with local organizations and nearby communities was the creation of the PAMiR on November 7th 2007, gathering more than 20 local groups and associations. In October 2009, the PAMiR became a founding member of the State Coordinator Against Waste Incineration in Cement Plants (CECIRC), a Spanish network of local movements against RDF use in cement kilns that hold annual meetings and organize joint protest actions. The Coordinadora Catalana Contra la Incineració (CCI) was created in May 2014 as a regional version of the CECIRC, with its members meeting on a quarterly basis going forward. These coordination bodies mainly aim at fostering alliances between local and international movements, as well as developing joint actions by also attracting other EJ groups interested in issues such as climate justice (Herrero and Vilella, 2018). As a result of these efforts, Can Sant Joan successfully hosted the second international meeting against waste incineration in cement kilns in 2015 with the support of GAIA (Global Alliance for Incinerator Alternatives) network, representing over 800 grassroots groups in 90 countries. Such initiatives enabled PAMiR to both be more visible and gather support from multiple environmental groups at different levels. Close contact with national and transnational environmental networks also allowed local movements against RDF use to reach engaged scientists and practitioners. This is a particularly crucial point since-as in other EJ struggles-knowledge co-production has been a very valuable asset in legitimizing the struggles in Can Sant Joan. Alliances among communities have allowed the sharing of this knowledge and other resources, while building and reinforcing a common subaltern identity around concerns on environmental health and the political economy of RDF use.

Through networking, local communities facing the specific problem of waste incineration in cement kilns also found support in each other, to the extent that they are still strategizing joint forms of action and embarking on knowledge co-production. More recently, community groups in Can Sant Joan paid special attention to establish alliances with other communities having similar RDF-related grievances, as well as with transnational environmental organizations. Even so, while the arguments of the movement against RDF use in Can Sant Joan are deeply rooted in the tradition of EJ against incineration, energy implications of this refusal are often sidelined. Given the global momentum that energy democracy is gathering beyond a sole focus on electricity generation, we find it interesting to explore the potentials of opposition against RDF use in cement production. 
This imaginably encompasses a revitalized movement toward rethinking energy infrastructures as more than waste-to-energy, promoting collective ownership and debating democracy beyond the nation-state (Bridge et al., 2018b).

\section{DISCUSSION}

\begin{abstract}
"Chulo... que muchos quedaron en el intento y movilizaciones del pueblo x la fábrica de cemento Otro intento de respirar aire fresco En el pueblo donde levantamos nuestros cimientos" (Many failed in the attempt and popular mobilizations against the cement plant Another attempt to breathe clean air in the town where we laid our foundations)

Excerpt of the rap song for the 50th anniversary of the Can Sant Joan neighborhood association written by Javier Cuesta Rojas in 2009 (Gómez and Conejero Antorán, 2017).
\end{abstract}

In analyzing the RDF related environmental conflicts in Can Sant Joan, we first start by suggesting ways in which energy justice and energy democracy could complementarily fit the local movement's grievances. Following this, we suggest some ideas through which an energy democracy framing can potentially energize the anti-RDF movement. Then, we move on to present the case of Catalan Network for Energy Sovereignty (Xse) and evaluate a potential coalition between Xse and PAMiR. Here the gist of our argument has two main dimensions. Principally, we observe a need for local movements to be energized by connecting with other struggles across scales to tap new political opportunity structures. Secondly, we argue that regional, national and transnational advocacy networks can enable these structures by bringing a democracy/justice edge to RDF related conflicts. We now address each of the two dimensions in turn.

\section{Energizing the Movement Against RDF in Can Sant Joan}

The praxis on energy justice and energy democracy both possess transformative potentials that could enhance the strength of the movement against RDF in Can Sant Joan. As we previously presented, despite sharing similar societal goals, the protagonists, the key agent of change and the intervention points of these two concepts diverge. An energy justice approach to the struggle against RDF in Can Sant Joan could add on to the environmental health axis of the movement by strategically linking it to energy concerns. Energy justice framing could potentially give way to an informed demand from the authorities in designing wasteto-energy policies with better public participation and, even in its extreme versions, with right-to-veto. A comprehensive understanding of the energy system as stressed by energy justice scholars (Jenkins et al., 2014; Heffron and McCauley, 2017) ensures RDF, as a hybrid issue of study between waste and energy, is considered as part of the broader energy metabolism. In fact, the analytical principles that energy justice scholars (Sovacool and Dworkin, 2014; Sovacool et al., 2017; Delina and Sovacool, 2018) have developed over the years could be complemented with insights from environmental health (Hernández, 2015). In this way, a joint assessment of energy justice principles and environmental health priorities could be operationalized and, eventually, lead to more stringent regulations in RDF use. Such a convergence between policy frameworks provided by the analytical tools of energy justice and the empirical insights from environmental health could be beneficial for policy design.

Complementarily, energy democracy's attention to power dynamics, as embedded in the materialities and imaginaries of the energy system, also provide certain possibilities. By centering the opposition around political economic dynamics of cement production and energy ownership, energy democracy could produce a new momentum in thinking beyond fixing the shortcomings of policy processes. Since a key feature of energy democracy is its useful vagueness (van Veelen and van der Horst, 2018), the possibilities offered by this convergence are multiple. In line with Hess's (2018) argument that absence of a clear definition provides room for forging alliances, energy democracy can prove useful to challenge the basic assumptions regarding the inevitability of waste, as much as it can also be used to challenge the energetic metabolism of cement production. Local anti-RDF activists have thus far succeeded in politicizing cement production and waste incineration. Taking this a step further, energy democracy could contribute to adding an energy dimension to the political ecologies narratively deployed by the PAMiR. Moreover, the sense of opportunity that energy democracy sees in technological transitions to affect political transformations (van Veelen, 2018) could be infused to the local movement. Thus, the PAMiR could enhance its already politicized actions by portraying their claim of phasing-out RDF facilities as an opportunity to democratize not only energy production, but also waste management and even cement production. This will not only allow the emergence of a new narrative, but also allow exploiting political opportunity structures beyond the state (Pellow, 2018). In this way, energy democracy framing could energize the movement with demonstrating (a) how a politics of possibility is shaped by the subaltern character of the community; (b) how networking among regional, national and transnational actors could push for radical political change; and (c) how the anti-RDF movement can articulate a politics beyond the company and the state, toward reclaiming autonomy in the particular political context of Catalonia (ibid.).

In further exploring the ways in which energy democracy might energize the anti-RDF movement in Can Sant Joan, we particularly find the resist, reclaim and restructure framework useful (Burke and Stephens, 2017). First, Can Sant Joan community is trying to resist the political economic feedback processes that deliberately place environmental burdens on the shoulders of subaltern communities. During the last five decades, local residents have carried out countless struggles against an abnormally high placement of unwanted infrastructures in the neighborhood. The closure of the urban waste incinerator in 2004 proved to be just an apparent victory; 2 years later the waste incinerator was substituted by RDF use in the cement plant. This event reassured the position of Can Sant Joana community that claims to have been targeted as a sacrifice zone and tackles corporate and governmental power as liable. Second, the movement against $\mathrm{RDF}$ also seeks to restructure the neoliberal capitalist logic of production; a logic that prioritizes 
industrial profitability of waste disposal and cement sector over the provision of needs and well-being of communities. Can Sant Joan activists indeed see their opposition to RDF as an opportunity to revert a power grab by elites, who are profiting from the double business of waste disposal and the windfall profits from carbon markets (see also Silver, 2017). Yet, the movement against RDF use in Can Sant Joan does not explicitly reclaim control of neither the waste management nor the energy production sectors. Thus, the community resists structural oppression and claims for the restructuration of the economic system that enhances inequalities. Yet, unlike energy democracy advocates, they have never reclaimed democratic control over the activities that are polluting them. We believe that the increasing attention on double materiality of democracy (Pichler et al., 2018), including both social materiality (i.e., social relations that connect communities to the biophysical world) and biophysical materiality (i.e., democratic control of production and consumption processes), is also a crucial discussion to consider at this point.

Here we see a fruitful tension, since raising energy democracy concerns in the struggle against RDF in Can Sant Joan could potentially add a new emphasis on reclaiming. But what does reclaiming mean in this context? First of all, it means the "right to have the rights" (in Hannah Arendt's sense of the phrase), as equal citizens of democratically deciding what type of energy, waste management, and economic systems are in place. And second, being able to reclaim and collectively decide on the public control of those activities. There are many implications, though, in decentralizing waste and energy systems and bringing power back to the public in a subaltern community. Just consider that cement produced in Can Sant Joan is sold internationally, while urban waste incinerated in the kiln is brought from 19 municipalities, and sewage sludge that is integrated in the RDF mix comes from a plant that gives service to 360,000 people ${ }^{5}$. This clearly shows the role of Can Sant Joan as a sacrifice zone suffering structural environmental discrimination, in a multi-layered and multi-scalar political economic configuration. Thus, one can say that probably the hardest step for subaltern communities is to reclaim ownership of the very structures that give rise to their grievances. Public control of resources cannot be reclaimed until structural discrimination processes are resisted and the multi-layered political economic dynamics are restructured. However, by even rhetorically raising the issue of reclaiming, the movement against $\mathrm{RDF}$ in Can Sant Joan could complement their ongoing struggle with an eye on autonomy. As Stirling (2014) underlines, socio-economic, political and cultural power is necessary for societal transformation in the context of energy debates. Nonetheless, power itself also needs to be transformed in due process. An understanding of reclaiming power as mending "asymmetrically structured agency" could, in this sense, help to move toward "hopeinspired alternative choices" (ibid.: 89). This makes energy democracy, regardless of its ambiguity and uncertainty, not

\footnotetext{
${ }^{5}$ To add on the environmental inequalities, the sewage treatment plant is also located in Can Sant Joan, constantly causing bad smell in the neighborhood and occasionally discharging effluents into the Besós river.
}

only an analytical framework to assess injustices, but also a pivotal normative commitment to reclaim autonomy for the communities (ibid.).

\section{The Catalan Energy Sovereignty Network: A Potential Ally Against RDF?}

Formed in 2013, the Catalan Energy Sovereignty Network (Xse in short) is comprised of more than 30 organizations which seek to transform the Catalan energy landscape following social and environmental justice criteria. Despite using the term energy sovereignty, energy democracy also strongly resonates with Xse. Its foundational manifesto suggests that energy production must respond to citizen demand and yield positive results on behalf of local communities, which in turn must obtain control and decision-making power over energy production means (Xarxa per la Sobirania Energètica, 2013). This framing brings to mind Szulecki's (2018) definition of energy democracy, in which the prosumer (Ritzer, 2010) has a central role. According to Xse, five specific criteria are also developed as dimensions that need to be integrated when developing the new energy system, in order to reach the ultimate goals of equity, respect for human rights, and harmony with the environment. They are: democracy, social control of the means of production, sustainability, energy degrowth, and decentralization and roots in the community. The emphasis on decentralization, social control and communities is of particular political importance here, given the role that uneven energy security plays in hindering "Catalonia's capacity to currently achieve a higher level of self-reliance in energetic terms" (Rosas-Casals et al., 2014). Nonetheless, as Hess (2018) and Burke (2018) argue, the absence of a narrow framing for energy democracy might be seen as an advantage here, rather than a weakness. It enhances the potential for advocates of energy democracy to build solidarities between organizations with diverse goals and has the potential to create fruitful tensions between their different transition narratives (as exemplified in the diverse membership patterns of $\mathrm{Xse}^{6}$ ). At this point, we argue for mutual benefits and new political possibilities in framing anti-RDF movements within the Xse.

We observe Xse as a "boundary organization" which can give leverage to the layered and scaled grievances of the antiRDF movement in Can Sant Joan. Since energy conflicts are "characterized by distinct asymmetries in power, influence and resources available to different actors" (Bridge et al., 2018a, p. 176), boundary organizations have a crucial role to play in mending these asymmetries. Xse's manifesto states its clear intention to eliminate the fossil fuel and nuclear power based energy system in Catalonia with strong aspirations for self-rule. Considering that RDF is, thus far, not explicitly addressed by Xse, framing RDF use as a matter of concern for energy democracy in the highly polluting process of cement production is not only being sidelined by local activists in Can Sant Joan-and

\footnotetext{
${ }^{6}$ The Catalan Energy Sovereignty Network (Xse) currently comprises 30 organizations of very diverse nature, ranging from an energy production and distribution cooperative (Som Energia), to a peasants' union (Unió de Pagesos), to different environmental groups (i.e., Ecologistes en Acció, Greenpeace etc.).
} 
the different networks that they belong to-but also, by Catalan energy democracy advocates.

Yet, we still see a fertile ground here. Although for some $\mathrm{RDF}$ is arguably in line with global sustainability concerns (mainly because of the fact that it reuses waste to produce energy and it indirectly avoids a certain amount of GHG emissions), it clashes with societal concerns in a way that blocks alternative narratives from emerging. First of all, RDF bypasses social control and collective ownership by the affected communities. The community of Can Sant Joan do not have any decision-making power over the production or consumption of energy at the cement plant nor can claim any right to energy ownership through the use of waste therein. Consequently, RDF use through waste incineration translates exclusively to profit for the owners of the cement plant, at the cost of health and quality of life of the community. Secondly, RDF creates additional benefits at the expense of community. Energy from waste in the Asland cement plant is produced and controlled by the multinational corporation LafargeHolcim, whose business interest is to promote further consumption of waste and cement in order to keep benefiting from the waste disposal business, while simultaneously obtaining windfall profits in the European carbon markets. The cement sector is the second biggest beneficiary of EU ETS after the power sector, with Carbon Market Watch (2016) reporting cement companies in Spain harvesting "almost 800 million euros from receiving too many allowances and selling this surplus for a profit on the market." Thirdly, by focusing on a technological fix, a focus on RDF sidelines the critical discussions on the growth-at-allcost model. Avoiding the societal debate on energy downscaling simply obscures the fact that more energy from RDF implies the continuous demand for more waste production. Finally, RDF is a highly-centralized energy source which assumes a topdown governance of waste, rooted in a reductive framing of sustainability.

In practical terms, we observe that by mobilizing "convergence as a political strategy" (Tramel, 2018) PAMiR and Xse may have mutual benefits, not least by expanding the frontiers of energy democracy. After all, Xse seeks to achieve "social empowerment that will transform the structures of oligopoly and create new realities from below, by those at the bottom for those at the bottom" (Cotarelo et al., 2014), a political desire shared equally by PAMiR. The solidarities forged between Xse and PAMiR will not only open new strategic paths of collaboration, reach a wider audience and gain visibility, but also bring onboard the burning questions on self-rule of energy from the local to regional. As a matter of fact, in July 2017, Catalan parliament passed a law aiming at territory-wide emissions reductions of $40 \%$ by $2030,65 \%$ by 2040 , and $100 \%$ by 2050 . While being a bold target, this law was eventually overturned by the Spanish constitutional court in December 2017, with important implications for the survival of nuclear plants in the autonomous region (BOE, 2017). In a context of high political confrontation, such decisions also have implications for the energy democracy drive of Xse in forming a counter-hegemonic narrative. We argue that anti-RDF movement's convergence with Xse could similarly empower community claims for democratic decision-making power over the energy and waste infrastructures that are deeply affecting their lives. Finally, the PAMiR could help the Xse to advance energy democracy at multiple scales, which according to Szulecki (2018), should be one of the main goals of the movement. The strong networks that the local anti-RDF movement has been able to knit at Spanish and international level could be a vehicle for raising energy democracy concerns within the global anti-RDF movement.

\section{CONCLUSION}

Through the Can Sant Joan case study, we have shown how movements against RDF are deeply rooted in the EJ tradition of struggles against waste incineration. As such, they often sideline energy issues associated with these conflicts. In their quest for an energy transition toward renewable energies, energy justice and energy democracy have usually overlooked the role of waste-to-energy infrastructures. Nevertheless, we argue that the movements against RDF use could be energized through converging with politically like-minded movements targeted at energy democracy. The multi-layered and multi-scalar nature of governance challenges around energy, waste, and cement production makes energy democracy a good framing for the movement against RDF in Can Sant Joan. We argue that a strategic convergence could potentially strengthen the local movement in Can Sant Joan to scale up its demands for justice, fairness and sustainability but also ownership while expanding the horizons of energy democracy for Xse. Establishing an alliance between PAMiR and Xse would equally boost fruitful internal tensions among EJ and energy democracy communities toward a more inclusive and democratic future. As a final note, we also see important opportunities for the researchers of first world political ecology to expand the research frontiers by looking "up, in and near" (Robbins, 2002), in dissecting political ecologies of the state (both national and sub-national in the particular case of Catalonia, see also Harris, 2017). In so doing, they go beyond a narrow, localized understanding of struggles for energy democracy. Our humble contribution here rests on bridging EJ research with energy democracy through illustrating the opposition to RDF in Can Sant Joan. This said, we believe there is further need to scrutinize waste-to-energy infrastructures in the light of energy democracy. A starting point for doing so is by not taking RDFs as energy sources at their face value.

\section{DATA AVAILABILITY STATEMENT}

The raw data supporting the conclusions of this manuscript will be made available by the authors, without undue reservation, to any qualified researcher.

\section{AUTHOR CONTRIBUTIONS}

SR and ET conceived the idea. SR conducted the fieldwork and wrote the manuscript. ET edited and improved it substantially. 


\section{ACKNOWLEDGMENTS}

We would like to thank the editor and two reviewers for their insightful comments. We also would like to thank Marco Armiero for his guidance and mentorship of SR during the fieldwork that led to this article and to Alex

\section{REFERENCES}

Abramsky, K. (ed.). (2010). Sparking a Worldwide Energy Revolution: Social Struggles in the Transition to a Post-Petrol World. Chico, CA: AK Press.

Agyeman, J., Schlosberg, D., Craven, L., and Matthews, C. (2016). Trends and directions in environmental justice: from inequity to everyday life, community, and just sustainabilities. Annu. Rev. Environ. Resour. 41, 321-340. doi: 10.1146/annurev-environ-110615-090052

Akhmat, G., Zaman, K., Shukui, T., and Sajjad, F. (2014). Does energy consumption contribute to climate change? Evidence from major regions of the world. Renew. Sust. Energy Rev. 36, 123-134. doi: 10.1016/j.rser.2014.04.044

Arbiol Ballarín, M. (2015). Informe Dinàmica de la Població de Montcada i Reixac 2014. Comparatiu altres anys. Montcada i Reixac: Unitat Tècnica d'Integració.

Armiero, M., and De Angelis, M. (2017). Anthropocene: victims, narrators, and revolutionaries. S. Atl. Q. 116, 345-362. doi: 10.1215/00382876-3829445

Armiero, M., and Sedrez, L. (eds.) (2014). A History of Environmentalism: Local Struggles, Global Histories. Bloomsbury.

Baltasar i Albesa, F. (2008). Resolució de 29 d’abril de 2008, per la qual s'adequa a la Llei 3/1998 i s'atorga, a l'empresa Lafarge Cementos S.A. l'autorització ambiental per a una activitat de fabricació de ciment emplaçada a la carretera $C-17 \mathrm{Km}$ 3 del terme municipal de Montcada i Reixac. Barcelona: Departament de Medi Ambient i Habitatge. p.6.

Becker, S., and Naumann, M. (2017). Energy democracy: mapping the debate on energy alternatives. Geogr. Compass 11:e12321. doi: 10.1111/gec3.12321

Bickerstaff, K., Walker, G., and Bulkeley, H., (eds.). (2013). Energy Justice in a Changing Climate: Social Equity and Low-Carbon Energy. London: Zed Books.

BOE (2017). Recurso de Inconstitucionalidad Contra Determinados Preceptos de la Ley de la Generalidad de Cataluña 16/2017, de 1 de Agosto, del Cambio Climático. Available online at: http://canviclimatic.gencat.cat/web/.content/ home/actualitat/docs/BOE-A-2017-14164.pdf

Bozuwa, J. (2018). Public Ownership for Energy Democracy. Available online at: https://thenextsystem.org/learn/stories/public-ownership-energy-democracy (Accessed October 18, 2018).

Bras, I., Silva, M. E., Lobo, G., Cordeiro, A., Faria, M., and de Lemos, L. T. (2017). Refuse Derived Fuel from Municipal Solid Waste rejected fractions-a case study. Energy Procedia 120, 349-356. doi: 10.1016/j.egypro.2017.07.227

Bridge, G., Barr, S., Bouzarovski, S., Bradshaw, M., Brown, E., Bulkeley, H., et al. (2018a). Energy and Society: A Critical Perspective. Oxford: Routledge. doi: 10.4324/9781351019026

Bridge, G., Ozkaynak, B., and Turhan, E. (2018b). Energy infrastructure and the fate of the Nation: introduction to special issue. Energy Res. Soc. Sci. 41: 1-11. doi: 10.1016/j.erss.2018.04.029

Bullard, R., and Johnson, G. (2000). Environmental justice: grassroots activism and its impact on public policy decision making. J. Soc. Issues 56, 555-578. doi: 10.1111/0022-4537.00184

Bullard, R. D. (1990). Dumping in Dixie: Race, Class, and Environmental Quality. Boulder, CO: Westview Press.

Burke, M. J. (2018). Shared yet contested: energy democracy counter-narratives. Front. Commun. 3:22. doi: 10.3389/fcomm.2018.00022

Burke, M. J., and Stephens, J. C. (2017). Energy democracy: goals and policy instruments for sociotechnical transitions. Energy Res. Soc. Sci. 33, 35-48. doi: 10.1016/j.erss.2017.09.024

Burke, M. J., and Stephens, J. C. (2018). Political power and renewable energy futures: a critical review. Energy Res. Soc. Sci. 35, 78-93. doi: $10.1016 /$ j.erss.2017.10.018

Carbon Market Watch (2016). Cement's Pollution Windfall From the EU ETS. Available online at: https://carbonmarketwatch.org/wp-content/uploads/2016/
Franklin from the Center for Agroecology, Water and Resilience at Coventry University for her professional English proofreading. SR's work was partially supported by the RECOMS project, funded by the European Commission. We gratefully acknowledge the open access funding from KTH ABE School.
11/Cement-windfall-from-the-ETS_4page_final.pdf (Accessed October 18, 2018).

CEMBUREAU (2013). The Role of Cement in the 2050 Low Carbon Economy. Brussels: The European Cement Association.

Chatziaras, N., Psomopoulos, C. S., and Themelis, N. J. (2016). Use of waste derived fuels in cement industry: a review. Manag. Environ. Q. 27, 178-193. doi: 10.1108/MEQ-01-2015-0012

Corburn, J. (2005). Street Science. Community Knowledge and Environmental Health Justice. Cambridge, MA: MIT Press.

Cotarelo, P., Llistar, D., Perez, A., Guillamon, A., Campuzano, M., and Berdie, L. (2014). Defining Energy Sovereignty, El Ecologista, Ecologistas en Acción Magazine $n^{\circ}$ 81, Summer 2014. Available online at: https://www.odg.cat/sites/ default/files/energy_sovereignty_0.pdf (Accessed October 18, 2018).

CTCN (2015). Report on the Technical Feasibility Study for RDF Production and its Use as Fuel in Cement Factories. Copenhagen: Climate Technology Center and Network.

Cutter, S. L. (2006). Hazards, Vulnerability and Environmental Justice. Boca Raton, FL: Routledge.

Delina, L. L., and Sovacool, B. K. (2018). Of temporality and plurality: an epistemic and governance agenda for accelerating just transitions for energy access and sustainable development. Curr. Opin. Environ. Sust. 34, 1-6. doi: 10.1016/j.cosust.2018.05.016

Demaria, F., and Schindler, S. (2016). Contesting Urban metabolism: struggles over waste-to-energy in Delhi, India. Antipode 48, 293-313. doi: 10.1111/anti.12191

Di Chiro, G. (2008). Living environmentalisms: coalition politics, social reproduction, and environmental justice. Environ. Polit. 17, 276-298. doi: 10.1080/09644010801936230

Di Chiro, G. (2016). "Environmental Justice," in Keywords for Environmental Studies, 1st Edn. eds J. Adamson, W. Gleason, and D. Pellow (New York, NY; London: New York University Press), 100-105.

Donoso, M. (2017). In Mexico: Time to End 'Sacrifice Zones.' Available online at: https://zerowasteeurope.eu/2017/12/in-mexico-time-to-end-sacrifice-zones/

Duda, J., Hanna, T., and Burke, M. (2017). Building Community Capacity for Energy Democracy: A Deck of Strategies. The Next System Project. Available online at: https://thenextsystem.org/learn/collections/building-communitycapacity-energy-democracy-deck-strategies (Accessed October 18, 2018).

Energy Justice Network (2018). Fact Sheet: Trash Incineration ("Waste-toEnergy"). Available online: http://www.energyjustice.net/files/incineration/ trashincineration.pdf (Accessed: October 18, 2018).

European Commission (2017). The Role of Waste-to-Energy in the Circular Economy. COM(2017) 34 Final. Brussels: European Commission.

Faber, D. (2018). "The political economy of environmental justice," in The Routledge Handbook of Environmental Justice, eds R. Holifield, J. Chakraborty, and G. Walker (Oxon; New York, NY: Routledge), 61-73.

Fairchild, D., and Weinrub, A. (2017). Energy Democracy: Advancing Equity in Clean Energy Solutions. Washington, DC: Island Press. doi: 10.5822/978-1-61091-852-7

Franklin, M. (2017). Case study: "We have a right to breathe clean air". Zero Waste Europe. Available online at: https://zerowasteeurope.eu/2017/11/casestudy-right-breathe-clean-air

Fuller, S., and McCauley, D. (2016). Framing energy justice: perspectives from activism and advocacy. Energy Res. Soc. Sci. 11, 1-8. doi: $10.1016 /$ j.erss.2015.08.004

García-Pérez, J., Fernández-Navarro, P., Castelló, A., López-Cima, M. F., Ramis, R., Boldo, E., et al. (2013). Cancer mortality in towns in the vicinity of incinerators and installations for the recovery or disposal of hazardous waste. Environ. Int. 51, 31-44. doi: 10.1016/j.envint.2012.10.003 
García-Pérez, J., López-Abente, G., Castelló, A., González-Sánchez, M., and Fernández-Navarro, P. (2015). Cancer mortality in towns in the vicinity of installations for the production of cement, lime, plaster, and magnesium oxide. Chemosphere 128, 103-110. doi: 10.1016/j.chemosphere.2015. 01.020

Gómez, M., and Conejero Antorán, J. L. (2017). "Territorio y discriminación ambiental: conflictos distributivos por ubicación de vertederos e incineradoras," in Ecología Política de la Basura. Pensando los Residuos Desde el Sur, ed M. F. Solíz T (Quito: Ediciones Abya-Yala and Instituto de Estudios Ecologistas del Tercer Mundo), 269-289.

Groves, C. (2015). The bomb in my backyard, the serpent in my house: environmental justice, risk, and the colonisation of attachment. Environ. Polit. 24, 853-873. doi: $10.1080 / 09644016.2015 .1067348$

Harris, L. M. (2017). Political ecologies of the state: recent interventions and questions going forward. Polit. Geogr. 58, 90-92. doi: 10.1016/j.polgeo.2017.03.006

Healy, N., and Barry, J. (2017). Politicizing energy justice and energy system transitions: Fossil fuel divestment and a "just transition". Energy Policy 108, 451-459. doi: 10.1016/j.enpol.2017.06.014

Heffron, R. J., and McCauley, D. (2014). Achieving sustainable supply chains through energy justice. Appl. Energy 123, 435-437. doi: 10.1016/j.apenergy.2013.12.034

Heffron, R. J., and McCauley, D. (2017). The concept of energy justice across the disciplines. Energy Policy 105, 658-667. doi: 10.1016/j.enpol.2017.03.018

Hernández, D. (2015). Sacrifice along the energy continuum: a call for energy justice. Environ. Justice 8, 151-156. doi: 10.1089/env.2015.0015

Herrero, A. (2015). Waste Incineration Fuelled Cement Plant in Montcada i Reixac, Spain, EJ Atlas. Available online at: https://ejatlas.org/conflict/wasteincineration-fuelled-cement-plant-in-montcada-i-reixac-spain (Accessed October 1, 2018).

Herrero, A., and Vilella, M. (2018). 'We have a right to breathe clean air': the emerging environmental justice movement against waste incineration in cement kilns in Spain. Sust. Sci. 13, 721-731. doi: 10.1007/s11625-017-0473-x

Hess, C. E. E., and Ribeiro, W. C. (2016). Energy and environmental justice: closing the gap. Environ. Justice 9, 153-158. doi: 10.1089/env.2016.0017

Hess, D. J. (2018). Energy democracy and social movements: a multi-coalition perspective on the politics of sustainability transitions. Energy Res. Soc. Sci. 40, 177-189. doi: 10.1016/j.erss.2018.01.003

IEA (2018a). Cement. Available online at: https://www.iea.org/tcep/industry/ cement/ (Accessed October 18, 2018).

IEA (2018b). Tracking Clean Energy Progress: Industry. International Energy Agency. Available online at: https://www.iea.org/tcep/industry/ (Accessed June 7, 2018).

IEA and CSI (2018). Technology Roadmap. Low-Carbon Transition in the Cement Industry. Paris: International Energy Agency.

Jenkins, K. (2018). Setting energy justice apart from the crowd: lessons from environmental and climate justice. Energy Res. Soc. Sci. 39, 117-121. doi: 10.1016/j.erss.2017.11.015

Jenkins, K., McCauley, D., Heffron, R., and Stephan, H. (2014). Energy justice, a whole systems approach. Queens Polit. Rev. 2, 74-87. Available online at: https://queenspoliticalreview.files.wordpress.com/2014/10/article-5energy-justice-a-whole-systems-approach-p74-87.pdf

Jenkins, K., Sovacool, B. K., and McCauley, D. (2018). Humanizing sociotechnical transitions through energy justice: an ethical framework for global transformative change. Energy Policy 117, 66-74. doi: 10.1016/j.enpol.2018.02.036

Kajaste, R., and Hurme, M. (2016). Cement industry greenhouse gas emissionsmanagement options and abatement cost. J. Clean. Prod. 112, 4041-4052. doi: 10.1016/j.jclepro.2015.07.055

Kara, M. (2012). Environmental and economic advantages associated with the use of RDF in cement kilns. Resour. Conserv. Recycling 68, 21-28. doi: 10.1016/j.resconrec.2012.06.011

Kunze, C., and Becker, S. (2014). Energy Democracy in Europe: A Survey and Outlook. Brussels: Rosa Luxemburg Stiftung.

Lang, G., and $\mathrm{Xu}, \mathrm{Y}$. (2013). Anti-incinerator campaigns and the evolution of protest politics in China. Environ. Polit. 22, 832-848. doi: 10.1080/09644016.2013.765684
Laurian, L., and Funderburg, R. (2014). Environmental justice in France? A spatiotemporal analysis of incinerator location. J. Environ. Plan. Manag. 57, 424-446. doi: 10.1080/09640568.2012.749395

Leandro, M. (2012). "Tires," in Encyclopedia of Consumption and Waste: The Social Science of Garbage, Vol. 1, ed C. A. Zimring (Thousad Oaks, CA: Sage), 915-918. doi: 10.4135/9781452218526.n351

Lerner, S. (2010). Sacrifice Zones: The Front Lines of Toxic Chemical Exposure in the United States. Cambridge, MA: MIT Press.

Liedmann, B., Wirtz, S., Scherer, V., and Krüger, B. (2017). Numerical study on the influence of operational settings on refuse derived fuel co-firing in cement rotary kilns. Energy Procedia 120, 254-261. doi: 10.1016/j.egypro.2017.07.176

Martinez-Alier, J., Kallis, G., Veuthey, S., Walter, M., and Temper, L. (2010). Social metabolism, ecological distribution conflicts, and valuation languages. Ecol. Econ. 70, 153-158. doi: 10.1016/j.ecolecon.2010.09.024

Martinez-Alier, J., Temper, L., Del Bene, D., and Scheidel, A. (2016). Is there a global environmental justice movement? J. Peasant Stud. 43, 731-755. doi: 10.1080/03066150.2016.1141198

McCarthy, J. (2015). A socioecological fix to capitalist crisis and climate change? The possibilities and limits of renewable energy. Environ. Plan. A 47, 2485-2502. doi: 10.1177/0308518X15602491

Mikulčić, H., Klemeš, J. J., Vujanović, M., Urbaniec, K., and Duić, N. (2016). Reducing greenhouse gasses emissions by fostering the deployment of alternative raw materials and energy sources in the cleaner cement manufacturing process. J. Clean. Prod. 136, 119-132. doi: $10.1016 /$ j.jclepro.2016.04.145

Monteiro, P. J., Miller, S. A., and Horvath, A. (2017). Towards sustainable concrete. Nat. Mat. 16, 698-699. doi: 10.1038/nmat4930

Monyei, C. G., Jenkins, K., Serestina, V., and Adewumi, A. O. (2018). Examining energy sufficiency and energy mobility in the global south through the energy justice framework. Energy Policy 119, 68-76. doi: 10.1016/j.enpol.2018.04.026

Müller, N., and Harnisch, J. (2008). A Blueprint for a Climate Friendly Cement Industry. Gland: WWF Lafarge conservation partnership.

Pellow, D. (2000). Environmental inequality formation: toward a theory of environmental injustice. Am. Behav. Sci. 43, 581-601. doi: $10.1177 / 0002764200043004004$

Pellow, D. (2018). "Environmental justice movements and political opportunity structures," in The Routledge Handbook of Environmental Justice, eds R. Holifield, J. Chakraborty, and G. Walker. (Oxon; New York, NY: Routledge), $37-49$.

Pichler, M., Brand, U., and Görg, C. (2018). The double materiality of democracy in capitalist societies: challenges for social-ecological transformations. Environ. Polit. 1-21. doi: 10.1080/09644016.2018.1547260

Pirani, S. (2018). Burning Up: A Global History of Fossil Fuel Consumption. London: Pluto Press.

Reed, M. G., and George, C. (2011). Where in the world is environmental justice? Prog. Hum. Geogr. 35, 835-842. doi: 10.1177/0309132510388384

Revill, J. (2017). Cement Demand Set to Rise 1.5 Percent in 2018 - World Cement Association. Reuters. Available online at: https://uk.reuters.com/article/ uk-cement-outlook/cement-demand-set-to-rise-1-5- percent-in-2018-worldcement-association-idUKKBN1E61KD (Accessed October 18, 2018).

Ritzer, G. (2010). "Focusing on the prosumer," in Prosumer Revisited, eds B.-M. Birgit and H. Kai-Uwe (Berlin: Springer), 61-79.

Robbins, P. (2002). Obstacles to a First World political ecology? Looking near without looking up. Environ. Plan. A 34, 1509-1513. doi: 10.1068/ a34217

Rootes, C. (2009). Environmental movements, waste and waste infrastructure: an introduction. Environ. Polit. 18, 817-834. doi: 10.1080/096440109033 45587

Rosas-Casals, M., Marzo, M., and Salas-Prat, P. (2014). Sovereignty, robustness, and short-term energy security levels. Catalonia case study. Front. Energy Res. 2:16. doi: $10.3389 /$ fenrg. 2014.00016

Scanlan, J. (2005). On Garbage. Chicago, IL: Reaktion Books.

Scheidel, A., Temper, L., Demaria, F., and Martínez-Alier, J. (2018). Ecological distribution conflicts as forces for sustainability: an overview and conceptual framework. Sust. Sci. 13, 585-598. doi: 10.1007/s11625-017-0519-0

Schlosberg, D. (2009). Defining Environmental Justice: Theories, Movements, and Nature. Oxford: Oxford University Press. 
Shah, D., Tangri, N., Tyler, B., Hlebarov, I., and Wilson, M. (2013). Understanding Refuse Derived Fuel. Quezon: Global Alliance for Incinerator Alternatives/Global Anti Incinerator Alliance.

Silver, J. (2017). The climate crisis, carbon capital and urbanisation: an urban political ecology of low-carbon restructuring in Mbale. Environ. Plan. A 49, 1477-1499. doi: 10.1177/0308518X17700393

Simon, J. M. (2014). European Gathering Against Waste Incineration in Cement Kilns. Zero Waste Europe.Available online at: https://zerowasteeurope.eu/ 2014/11/european-gathering-against-waste-incineration-in-cement-kilns/ (Accessed June 8, 2018).

Skandier, C., and Bozuwa, J. (2018). An Anchor Strategy for the Energy Transition. Available online at: https://thenextsystem.org/learn/stories/anchor-strategyenergy-transition (Accessed October 18, 2018).

Sovacool, B. K., Burke, M., Baker, L., Kotikalapudi, C. K., and Wlokas, H. (2017). New frontiers and conceptual frameworks for energy justice. Energy Policy 105, 677-691. doi: 10.1016/j.enpol.2017.03.005

Sovacool, B. K., and Dworkin, M. H. (2014). Global Energy Justice. Cambridge: Cambridge University Press. doi: 10.1017/CBO97811073 23605

Stirling, A. (2014). Transforming power: social science and the politics of energy choices. Energy Res. Soc. Sci. 1, 83-95. doi: 10.1016/j.erss.2014. 02.001

Sze, J. (2006). Noxious New York: The Racial Politics of Urban Health and Environmental Justice. Cambridge, MA: MIT press.

Szulecki, K. (2018). Conceptualizing energy democracy. Environ. Polit. 27, 21-41. doi: 10.1080/09644016.2017.1387294

Tramel, S. (2018). Convergence as political strategy: social justice movements, natural resources and climate change. Third World Q. 1-18. doi: 10.1080/01436597.2018.1460196

Trumpeter, K. (2012). "Coal ash," in Encyclopedia of Consumption and Waste: the Social Science of Garbage, Vol. 1, ed C. A. Zimring (Thousad Oaks, CA: Sage), 131-132. doi: 10.4135/9781452218526.n55
TUED (2013). Resist, Reclaim, Restructure: Unions and the Struggle for Energy Democracy. Available online at: http://unionsforenergydemocracy.org/wpcontent/uploads/2014/05/resistreclaimrestructure_2013_english.pdf (Accessed October 18, 2018).

Valls Llobet, C. (2018). Medio Ambiente y Salud. Mujeres y hombres en un mundo de nuevos riesgos. Madrid: Ediciones Cátedra.

van Veelen, B. (2018). Negotiating energy democracy in practice: governance processes in community energy projects. Environ. Polit. 27, 644-665. doi: 10.1080/09644016.2018.1427824

van Veelen, B., and van der Horst, D. (2018). What is energy democracy? Connecting social science energy research and political theory. Energy Res. Soc. Sci. 46, 19-28. doi: 10.1016/j.erss.2018.06.010

WBCSD (2015). Low Carbon Technology Partnerships Initiative: Cement. Geneve; New York, NY; New Delhi: World Business Council for Sustainable Development.

Xarxa per la Sobirania Energètica, X. S. E. (2013). Manifest per la Sobirania Energètica. Geneve; New York, NY; New Delhi. Available online at: https://xse. cat/manifest/ (Accessed June 15, 2018).

Yin, R. (2003). Case Study Research: Design and Methods, 3rd Edn. Thousand Oaks, CA: Sage Publications.

Conflict of Interest Statement: The authors declare that the research was conducted in the absence of any commercial or financial relationships that could be construed as a potential conflict of interest.

Copyright (C) 2019 Ruiz Cayuela and Turhan. This is an open-access article distributed under the terms of the Creative Commons Attribution License (CC BY). The use, distribution or reproduction in other forums is permitted, provided the original author(s) and the copyright owner(s) are credited and that the original publication in this journal is cited, in accordance with accepted academic practice. No use, distribution or reproduction is permitted which does not comply with these terms. 